\title{
The Influence of a Methods Course in Physical Education on Preservice Classroom Teachers' Acquisition of Practical Knowledge
}

\author{
Jan-Erik Romar \\ Åbo Akademi University \\ Magnus Ferry \\ Umeå University
}

\begin{abstract}
Purpose: This study was framed with an explorative approach in which preservice classroom teachers (PCTs) participated in physical education learning activities. The purpose was to investigate the construction of their practical knowledge. Methods: Data collection was integrated into a methods course and included a written text assignment in which 28 PCTs described significant didactical milestones (practical knowledge) that will guide their future teaching in physical education. The qualitative analysis of the didactical milestones involved identifying the content of and arguments for their milestones and categorizing them based on common themes and categories. Results: The results showed that the content of the PCTs' practical knowledge was mainly pedagogical and focused most often on instructional strategies; the reasons were related to students and their learning processes. Conclusion: By exploring and understanding PCTs' learning of practical knowledge, teacher educators can help to bridge the gap between theory at university and the practice of teaching.
\end{abstract}

Keywords: classroom teacher education, higher education, knowledge acquisition, learning experiences

Given the complexity of teachers' work, the available research on classroom teachers who teach physical education (PE) has presented an interesting landscape. In most European countries, PE is predominantly taught by classroom teachers at the elementary grades (K-6; Hardman, 2005; Tsangaridou, 2012), and the majority of these teachers do not always provide quality PE learning experiences for their students (Fletcher \& Mandigo, 2012; Tsangaridou, 2016). Scholars have identified institutional factors outside of teachers' control contributing to this issue, such as time constraints, provision of initial teacher education (TE) and professional development opportunities, financial and human resources, and class sizes (Carse, Jess, \& Keay, 2018; Fletcher, Mandigo, \& Kosnik, 2013). For the most part, many primary classroom teachers have limited content knowledge in PE, lack appropriate skills and knowledge to teach PE, and do not feel confident in teaching PE (Dyson, Cowan, Gordon, Powell, \& Shulruf, 2018; Tsangaridou, 2012). Many teachers simply replicate their past personal experiences of PE as students in their own teaching of PE (Carse, 2015; Morgan \& Bourke, 2008). Furthermore, Elliot, Atencio, Campbell,

(C) 2020 The Authors. Published by Human Kinetics, Inc. This is an Open Access article distributed under the terms of the Creative Commons AttributionNonCommercial 4.0 International License, CC BY-NC 4.0, which permits the copy and redistribution in any medium or format, provided it is not used for commercial purposes, the original work is properly cited, the new use includes a link to the license, and any changes are indicated. See https://creativecommons.org/licenses/ by-nc/4.0. This license does not cover any third-party material which may appear with permission in the article. For commercial use, permission should be requested from Human Kinetics, Inc., through the Copyright Clearance Center (http://www. copyright.com).

Romar is with the Faculty of Education and Welfare Studies, Åbo Akademi University, Vasa, Finland. Ferry is with the Department of Education, Umeå University, Umeå, Sweden. Romar (jromar@abo.fi) is corresponding author. and Jess (2013) reported that among nonspecialist primary teachers in Scotland, their early school experiences of PE molded their beliefs about the subject, influenced their confidence of teaching $\mathrm{PE}$, and affected their teaching practices in PE. These teachers also commented that the limited time devoted to PE-specific training as part of their TE program did not adequately prepare them to teach PE. Therefore, as Tsangaridou (2012) suggested, classroom teachers' formal education experiences need to be studied more systematically to understand how classroom teachers end up teaching PE the way they do.

Preservice teachers enroll in TE programs, and during the TE process, they are expected to acquire PE knowledge, develop a professional identity, and start to think and act as teachers teaching PE in a school context (Pike \& Fletcher, 2014; Templin \& Schempp, 1989). The challenge for TE is to develop teachers with nuanced and balanced understanding of PE pedagogy; most elementary TE programs provide classroom teachers with one brief course in PE in addition to many other methods and pedagogy courses. International research during TE suggests that preservice classroom teachers' (PCTs) perceived competence and attitudes toward teaching $\mathrm{PE}$ are strongly related to their PE experiences as students and their personal history of physical activity (Kari, 2016; Morgan \& Bourke, 2008; Morgan \& Hansen, 2008; Webster, 2011). Thus, teacher educators should promote PCTs' reflections and critiques of prior experiences as students, although they concurrently teach content in a progressive manner (Hopper, 2015; Hyndman, 2017).

Although researchers have argued that PETE is relatively ineffective in altering the beliefs of PE preservice teachers (Pike \& Fletcher, 2014; Templin \& Richards, 2014), there is a growing global body of knowledge indicating that meaningfully designed courses in classroom TE can positively impact PCTs' development as teachers. After graduating from a 5-year comprehensive TE program in Finland, PCTs felt that they had sufficient PE content 
knowledge and experience of teaching PE, which resulted in their perceived competence of their ability to teach PE (Kari, 2016). A study from Ireland reported a change in the discourse of PCTs' understanding of the nature and purpose of $\mathrm{PE}$ between the beginning and end of the TE program (Ni Chróinín \& Coulter, 2012). In addition, Fletcher et al. (2013) found a positive significant change in Canadian PCTs' identities as teachers of PE, arguing that what and how they learned about teaching PE was different from what and how they learned in PE in school. Finally, Australian PCTs showed after completing one or more units with a focus on $\mathrm{PE}$ an increased self-reported preparedness to teach PE, which was also associated with building confidence and competence for new roles and responsibilities as teachers (Freak \& Miller, 2017). Even though teacher educators and researchers have been concerned with PCTs' perception of preparedness, identities as teachers in PE, and their self-efficacy in teaching PE, little empirical evidence exists that describes how classroom teachers learn to teach and how teachers' PE knowledge is acquired.

Although the previously mentioned research describes some success in elementary TE, Fletcher et al. (2013) noted that making informed choices about what and how to teach PCTs in one PE course is especially difficult when there is little evidence and/or direction about what teacher educators should focus on. They did, however, suggest that developing PCTs' confidence of teaching PE should be a major focus of these elementary PE courses. One of the major issues relating to the acquisition of PE content knowledge is the time allocated to the course and the need for face-to-face learning when instruction is practical and applied in nature (Freak \& Miller, 2017). Tsangaridou $(2012,2016)$ suggested that more emphasis be placed on content and pedagogical content knowledge of PE during TE; content and methods courses beyond the introductory level should be part of classroom TE. Kari (2016) also noted that when PCTs looked back on the TE program, they appreciated having had time to practice their movement skills; it provided feelings of competence, learning, and improved self-esteem; thus, building a foundation for them as teachers of PE. Finally, teacher educators in PE should include reflective teaching activities in their courses to help PCTs analyze teaching and learning situations from different perspectives (Tsangaridou, 2016).

\section{Theoretical Background}

There is a need in TE to understand PCTs' learning as a whole instead of what or how they think isolated from what they do (Borg, 2003). Research on teacher knowledge is closely related to TE practice with a main focus on supporting teacher learning (Borg, 2015; Puustinen, Säntti, Koski, \& Tammi, 2018). The concept of teacher knowledge has expanded significantly over time; the educational community has used various labels, indicating a relevant aspect of teacher knowledge. The variety of labels and their use in research is far from apparent or systematic. Stenberg, Karlsson, Pitkäniemi, and Maaranen (2014) and Borg (2003) pointed out that identical labels have been defined in different ways, and different labels have been used to describe similar concepts.

Several researchers have focused on teachers' practical knowledge (Clandinin, 1986; Elbaz, 1981). In her seminal work, Elbaz (1983) defined teachers' practical knowledge as "complex sets of understanding which teachers actively use to shape and direct their teaching" (p. 3). Moreover, Johnston (1992) referred to practical knowledge as the knowledge teachers use in complex classroom situations in a more holistic way; it was not viewed as a body of fixed, stable concepts applied to practice, but rather as transient, subject to change, and oriented to practice. When practical knowledge is constructed by teachers, it integrates experiential knowledge, formal knowledge, and personal beliefs (van Driel, Beijaard, \& Verloop, 2001). Thus, teachers' practical knowledge is not at odds with knowledge gained from lectures, self-instruction, and other sources of TE (Oonk, Verloop, \& Gravemeijer, 2015). Research suggests that teachers' practical knowledge can have a real impact on instructional decisions and actions in teaching PE (Rovegno, 1995; Tsangaridou, 2002).

Many researchers emphasize that teachers' practical knowledge is person specific and arises from their background, experience, and reflection (Berliner, 2004; Elbaz, 1991; Fenstermacher, 1994). The situation-specific nature of teaching and learning highlights the central role of context in shaping teachers' practical knowledge (Ben-Peretz, 2011; Rovegno, Chen, \& Todorovich, 2003). Finally, practical knowledge is often tacit or implicit, and teachers are not always able to articulate this type of knowledge (Berliner, 2004; Borg, 2015; Elbaz, 1991). There is a strong focus on the complexity of practical knowledge, as knowledge and beliefs are seen as inseparable, although beliefs are regarded as a personal component referring to individual values, attitudes, and ideologies, and knowledge as a content-related component with a focus on teachers' factual propositions (Meijer, Verloop, \& Beijaard, 2002; Witterholt, Goedhart, \& Suhre, 2016). Against this background, it has been argued that teachers' practical knowledge is the actual driving force behind teachers' cognition and behavior (Borg, 2015; Pitkäniemi, 2017). For example, Siedentop and Tannehill (2000) noted that PE teachers with strong practical knowledge can convert their knowledge about the content into actual instructional practices in complex situations.

Even though teachers' practical knowledge is clearly linked to personal experiences and individual situations, some features of practical knowledge are shared by many teachers, for instance, teachers who teach a certain subject (Verloop, Van Driel, \& Meijer, 2001). Scholars have identified categories of teachers' practical knowledge in general education as (a) subject matter, (b) students, (c) student learning and comprehension, (d) purposes, (e) curriculum, and (f) instructional techniques (Verloop et al., 2001; Witterholt et al., 2016). However, as with the use of practical knowledge as a term, researchers have structured the content of PCT' practical knowledge in slightly different ways (Buitink, 2009; He, Levin, \& Li, 2011; Levin \& He, 2008; Maaranen, Pitkäniemi, Stenberg, \& Karlsson, 2016; Pitkäniemi, Karlsson, \& Stenberg, 2014; Romar, Åström, \& Ferry, 2018). Our review of these studies in both general education and PE shows that these researchers have concentrated on similar themes in analyzing PCTs' practical knowledge, such as teachers, teaching and instructional activities, classroom context, students, sociocultural aspects, and curriculum. In general education, PCTs' practical knowledge was most often concerned with responsibilities of the teacher, instructional strategies, and classroom environment (Levin \& He, 2008; Pitkäniemi et al., 2014), whereas in PE, their practical knowledge focused mainly on instructional strategies and teacher responsibilities (Romar et al., 2018). Furthermore, Buitink (2009) noted that PCTs' well-developed practical knowledge showed a focus on students' learning processes and awareness of underlying principles of teaching.

Therefore, it was assumed that a practical knowledge approach would adequately guide this study to examine how PCTs' professional learning would be affected by their work in a classroom TE course in PE. Research on teachers' practical knowledge emphasizes the central role of personal knowledge, the situation-specific nature of learning, and that knowledge is often tacit or implicit, 
where beliefs and knowledge are seen as inseparable (Berliner, 2004; Borg, 2015; Elbaz, 1991; van Driel et al., 2001). Under this framework, PCTs are seen as active learners in gathering, processing, and applying information during a PE course to enhance their own learning and acquisition of knowledge related to teaching PE. Consequently, using a case study design, this study was framed with an explorative approach in which PCTs participated in PE learning activities. The purpose of this study was to investigate the construction of their practical knowledge. We divided our research question into three parts. First, what are the contents of PCTs' practical knowledge? second, how do the PCTs argue for their practical knowledge? and finally, how is the content connected to PCTs' reasons for placing importance on practical knowledge?

\section{Methods}

\section{Context of the Study}

The research setting was Åbo Akademi University located in western Finland where the faculty of education offers a preservice classroom TE program that is similar to most other TE programs in Finland. Classroom teachers teach all subjects including PE for the first six grades of elementary school in Finland. Research-based TE programs in Finland employ a structured systematic analysis of education approach (Maaranen et al., 2016). The aim of researchbased TE is to prepare responsible, autonomous, reflective professional teachers who can base their teaching on research principles to deal with practical teaching challenges (Krokfors et al., 2011). For an individual preservice teacher, this means developing the ability to analyze, develop critical awareness, and promote intellectual and personal development (Aspfors \& Eklund, 2017). PCTs graduate with a master's degree after 5 years of study, and the program consists of general education studies, methods courses related to school subjects, teaching practice, research methods, and research projects. To meet the classroom teacher qualification requirements, PCTs must complete 60 educational credits of coursework in different subject methods, of which one five-credit course is in PE. In addition, PCTs can elect to take further methods courses in specific subjects, of which one could be in PE. The study followed the general ethical standards approved by the scientific community (Finnish Advisory Board on Research Integrity, 2016), and informed consent was obtained from the students.

\section{Participants and Coursework}

The participants were second-year PCTs enrolled in an optional fivecredit PE methods course. The PCTs had earlier completed three semesters of general education studies and methods courses. This study included all 16 female and 12 male PCTs (around 21 years of age) in one course. All participants had taken the mandatory introduction to elementary PE methods course (five credits and 60 contact hours), during the previous semester. The specific learning objectives for the optional five-credits course in this study were that PCTs should (a) perform basic skills in different sport activities; (b) formulate and develop individual teaching plans and follow-up the development of an individual learner; (c) understand, describe, and evaluate how a school community can promote students' physical activity; and (d) independently plan, implement, and analyze teaching situations from different didactical perspectives. The PCTs met either two to three times a week (90-min sessions) for 17 weeks (64 contact hours). The learning objectives were approached in the practical teaching component of the course through experience-based content learning, while the participants explored different teaching formats in skiing, ball games, swimming, gymnastics, dance, and athletics. In these classes (56 contact hours), modeling effective PE pedagogy had a unique role because course instructors were teaching how to teach (Dack, 2018). When teacher educators model instructional strategies in their teaching, PCTs 'live the curriculum' and can construct their own meanings of teaching PE, increasing the likelihood that they will translate course content into their future teaching (Grossman et al., 2000). The PCTs also completed three assignments as part of this course, one specific to lesson planning and micro teaching conducted in local schools (one 90-min lesson), another to motor learning and tutor instruction (four 30-min peer-teaching lessons), and one to the "School on the Move" program. The Schools on the Move program is a government initiative, which uses a bottom-up approach to create a physically active culture in Finnish comprehensive schools. These assignments were presented and discussed in seminars (eight contact hours).

The course provided the PCTs with authentic forms of PE as a means to enhance their understanding of teaching PE, and such learning experiences enabled students to engage in knowledge construction through developing links between what is taught and what is learned. Thus, their practical knowledge is created from all course experiences and is used to support new learning, which is main tenets of constructivist pedagogy (Richardson, 2003). There is evidence that teacher educators, across different content areas, have used principles of constructivist teaching to design instruction and create a learning environment where preservice teachers show learning benefits from constructivist teaching experiences (Borko \& Putnam, 1996; Harfitt \& Chan, 2017).

\section{Data Collection and Analysis}

This study focused on the learning experiences of PCTs in a natural setting and offers an understanding of what their practical knowledge is and how they argue for it. Thus, a case study design was utilized, where the case under investigation was the PE methods course and the group of 28 students (Yin, 2017). Although previous studies on preservice teachers' practical knowledge and beliefs often have used surveys to collect data from all participants during one specific occasion, He et al. (2011) suggested that other data collection methods could be useful. We therefore chose to collect written texts from students, an approach which has been used to gain insight into preservice teachers learning during TE (Hosein \& Rao, 2017; Maaranen et al., 2016).

Our intention with this study was that PCTs should construct their practical knowledge along with the coursework (cf. Borko \& Putnam, 1996; Fairbanks et al., 2010) and, inspired by Ni Chróinín and O'Sullivan (2014), have the PCTs' voices captured through the written texts they produced during the course. Thus, in addition to the graded assignments presented in the seminars, the PCTs were asked, based on their experiences during the study course, to describe 10 significant didactical milestones (DMs; practical knowledge) that would guide their future teaching in PE. In this written reflective assignment, a DM was defined as a thought, theory, or philosophy that the PCTs believed could/should guide/ direct their future work as a teacher in PE. A DM was explained as an example of practical teacher knowledge, defined as the teacher's knowledge of teaching and practical challenges, and could thus be seen in meaningful actions. The aim of this process was for the PCTs to try to make implicit learning explicit (Borg, 2015) and to give them the opportunity to reflect on coursework in the form of their practical knowledge (Tsangaridou, 2012). Each DM was 
supposed to have a heading and a short description of what it meant to the PCT. During the 17-week course, PCTs had the opportunity to ask questions and were reminded several times to write down DMs and not leave the work until the last week (day) of the course. The data were not collected only for research; rather, it was one step in an ongoing process of encouraging PCTs to reflect on their practical knowledge (Tsangaridou, 2016), in addition to just participation in practical and theoretical activities.

A total of 280 DMs submitted by the PCTs were analyzed qualitatively and quantitatively to derive a comprehensive picture of the data. The development of coding categories involved an iterative process that required considering previous research about practical knowledge (Levin \& He, 2008; Romar et al., 2018) and exploring the content of the written data (cf. Silverman, 2011). For example, Niklas (pseudonym) wrote the heading "Modify the Game" to one of his DMs and then described what he meant: "It can be difficult to directly start to play the game with all the rules, skills, and strategies, so modify the game to make it easier." The qualitative content analysis involved identifying the content of participants' DMs and categorizing them on the basis of common themes and categories. Through this process, data were organized and sorted into four major themes: content (what), teacher (who), instructional strategies (how), and students (whom). Within these themes were several categories. The content DMs included curriculum, practice, and Schools on the Move. The teacher theme included competency and enthusiasm. The instruction theme included planning, modification, teaching methods, progression, concretization, feedback, play, technology, and teaching strategies. Finally, the students' theme included activity and learning, individualization, and empowerment. These categories became the basis for the descriptions of the PCTs' practical knowledge identified from their reflective writings. The quantitative analysis noted the frequency of the identified themes and categories from the content analysis of all DMs.

After categorization of every DM, the second research question was answered by searching each preservice teacher's DMs for instances where they argued for their DM, in total 105 quotations. In other words, we explored the reasons why PCTs believed that particular DMs were important in their teaching careers. For example, one of Sandra's DMs was "New Skills Through Play," and she argued in her writing that "it is important, particularly to younger students, that they learn skiing through playing games." A content analysis was conducted, in a similar way as in the first research question, to identify categories of reasons for PCTs' DMs (second research question). Through this process, data were organized into six categories: learning, active participation, competence and self-esteem, motivation, enjoyment, and fluent instruction. The quantitative analysis noted the frequency of the identified categories.

All data were analyzed after the PCTs had completed the course. The first author conducted the initial analysis, and the second author checked the analysis. The DMs in the PCTs' writings were coded independently by the researchers and categorized. Then, the coding analyses were compared, conflicts between the two authors were discussed, and a consensus with regard to coding the few discrepancies was resolved collaboratively by discussing the nature of the DM. The PCTs did not have to do additional work for this study, and their written assignments were not used for assessment purposes.

\section{Results}

The DM data suggest a typology of different approaches of practical knowledge that reflect how PCTs experience learning activities and develop their practical knowledge. First, results of the analysis of the content of DMs are presented according to four themes, ordered smallest to largest based on frequency scores: (a) teacher (who), (b) content (what), (c) students (whom), and (d) instruction (how). Second, the reasons for PCTs' practical knowledge are presented in six categories. Finally, the relationships between the content and reasons for PCTs' practical knowledge are exemplified in the results.

The smallest theme, teacher (who), consisted of 16 DMs organized into two categories: competency and enthusiasm (see Table 1). The competency DMs presented a view of how teachers need to have and develop content knowledge. In the enthusiasm

\section{Table 1 Categories of Content of Practical Knowledge About Who, What, and Whom (DMs)}

\begin{tabular}{|c|c|c|c|}
\hline Categories & No. & $\%$ & Examples of practical knowledge \\
\hline Who (teacher) & 16 & 6 & \\
\hline Competency & 9 & & $\begin{array}{l}\text { Teachers need to have didactic knowledge of what they teach } \\
\text { Upgrade yourself as a PE teacher }\end{array}$ \\
\hline Enthusiasm & 7 & & $\begin{array}{l}\text { The teacher should have an interest in what they teach } \\
\text { Meet others the same way you want to be treated! }\end{array}$ \\
\hline What (content) & 46 & 16 & \\
\hline Curriculum & 8 & & $\begin{array}{l}\text { Think about what is important in the content you teach } \\
\text { Physical education should have a clear goal that the student is informed of. }\end{array}$ \\
\hline Practice & 28 & & $\begin{array}{l}\text { It was a good task we had } \\
\text { Ski waxing is a very good content to cover }\end{array}$ \\
\hline Schools on the Move & 10 & & $\begin{array}{l}\text { Encourage activity and movement also outside of PE classes } \\
\text { [Physical] activity is much more than just school PE. }\end{array}$ \\
\hline Whom (students) & 59 & 21 & \\
\hline Activity and learning & 21 & & $\begin{array}{l}\text { To spend enough time on each task } \\
\text { That all students have as many throws as possible so that there is no waiting }\end{array}$ \\
\hline Individualization & 17 & & $\begin{array}{l}\text { Have tasks at different levels } \\
\text { Include all students and see possible variations in students' physical abilities as a strength. }\end{array}$ \\
\hline Empowerment & 21 & & $\begin{array}{l}\text { Have students sometimes make their own games with their own rules } \\
\text { They feel that they are part of the planning and that they practice taking responsibility }\end{array}$ \\
\hline
\end{tabular}

Note. DMs = didactical milestones $; \mathrm{PE}=$ physical education. 
category, DMs were linked to what kind of teachers participants should be, particularly regarding their interest in and empathy toward their students. The next theme, content (what) consisted of 46 DMs arranged into three categories: practice, Schools on the Move, and curriculum. In the practice category, the PCTs described actual practice tasks that they participated in during the course. The Schools on the Move category contained issues related to the fact that physical activity consists of much more than PE classes. DMs in the curriculum category dealt with the content and goal of PE as a school subject. The theme of students (whom) contained 59 DMs related to involving students in the learning process and was organized into three categories: activity and learning, individualization, and empowerment. DMs in the activity and learning category were linked to how students in PE should actively participate during lessons. The individualization category dealt with how to include all students in PE classes, and DMs in the empowerment category described how PCTs want to provide opportunities for students to be responsible and to make decisions.

The largest theme, instruction (how), consisted of 159 DMs related to teachers' everyday pedagogical work in teaching practices and included nine categories (see Table 2). The two largest categories were modification and teaching strategies; the modification category (43 DMs) dealt with how to adapt and apply developmentally appropriate teaching tasks from traditional sports in a school PE setting. The teaching strategy category contained 32 DMs dealing with practical cookbook such as examples of how to handle daily teaching situations in PE. DMs within the teaching methods category focused on how teachers organize PE lessons through stations, task sheets, and tutor instruction. The progression category concerned the need to organize instruction from easier to more demanding tasks. Other categories within the instruction theme were related to play, planning, technology, feedback, and concretization.

The second research question focused on the reasons the PCTs had for their practical knowledge in PE. Quotations in which they mentioned a reason for their DM were analyzed and organized into six different categories. Only one category was related to the teacherfluent instruction-which described what teachers can do to manage instruction (see Table 3). Interestingly, all the other categories for PCTs' reasons for their DMs were related to students (e.g., student learning and active participation as well as motivation, enjoyment, and competence, and self-esteem). The three largest categories were motivation, student learning, and active participation.

When the content of the DMs was related to the reasons for the DMs, several interesting patterns were noted (see Table 4). DMs focused on student activity, teacher feedback, and teachers showing concrete examples were important for PCTs mainly because of the contribution to student learning processes. Content categories of teaching methods and task modification were argued with reasons related to students' active participation and motivation. DMs with a focus on student individualization and task progression contributed mainly to student competence and self-esteem. The reasons for DMs with a focus on student engagement and play were related to student motivation and enjoyment. Finally, DMs associated with planning and technology were important in contributing to fluent instruction.

\section{Discussion}

The present study approached PCTs' understanding from a practical knowledge perspective (Elbaz, 1983) that implies that that teachers' practical knowledge is person specific where the context has a central role, although practical knowledge is often tacit or implicit knowledge. The purpose of this study was to utilize the voices of Finnish PCTs to form a detailed understanding about the construction of their practical knowledge. The mix of qualitative and quantitative analyses on two levels generated an in-depth understanding of PCTs' practical knowledge.

\section{Table 2 Categories of Content of Practical Knowledge About How (DMs)}

\begin{tabular}{|c|c|c|c|}
\hline Categories & No. & $\%$ & Examples of practical knowledge \\
\hline How (instruction) & 159 & 57 & \\
\hline Planning & 11 & & $\begin{array}{l}\text { Good planning is important } \\
\text { Have a clear plan for a lesson }\end{array}$ \\
\hline Modification & 43 & & $\begin{array}{l}\text { Skiing does not have to be skiing only around and around the track } \\
\text { Practice skills during track and field in the gymnasium } \\
\text { Instead of the traditional basketball game with students }\end{array}$ \\
\hline Teaching methods & 19 & & $\begin{array}{l}\text { Stations that we had } \\
\text { Tutor instruction is a good way of teaching } \\
\text { We tested task sheets }\end{array}$ \\
\hline Progression & 16 & & $\begin{array}{l}\text { Have a clear progression between the tasks } \\
\text { Here it is important that you start with the easier tasks and then move to more demanding }\end{array}$ \\
\hline Concretization & 7 & & $\begin{array}{l}\text { Concretize the skill execution } \\
\text { Use concrete items as [teaching] aids }\end{array}$ \\
\hline Feedback & 9 & & $\begin{array}{l}\text { Feedback is important, both positive and constructive } \\
\text { Important with feedback to students when they do something }\end{array}$ \\
\hline Play & 12 & & $\begin{array}{l}\text { It is important to integrate play in }[\mathrm{PE}] \text { teaching } \\
\text { Work on skills through games where the students practice a balance task }\end{array}$ \\
\hline Technology & 10 & & Technology and digital aids must also be included in PE \\
\hline Teaching strategies & 32 & & $\begin{array}{l}\text { Use home base with students in PE } \\
\text { The teacher can participate in the activities } \\
\text { There is always a teacher who makes up the teams } \\
\text { You form a rotating system so that all students dance with each other }\end{array}$ \\
\hline
\end{tabular}

Note. DMs = didactical milestones $; \mathrm{PE}=$ physical education. 
Table 3 Categories of Reasons for Practical Knowledge About Whom and How (DMs)

\begin{tabular}{|c|c|c|c|}
\hline Categories & No. & $\%$ & Examples of reasons for practical knowledge \\
\hline Learning & 21 & 20 & $\begin{array}{l}\text { So that the students actually learn } \\
\text { This helps students learn the task properly and correctly } \\
\text { In order to obtain the best possible results }\end{array}$ \\
\hline Active participation & 19 & 18 & $\begin{array}{l}\text { So that the students are active most of the time } \\
\text { All students have a chance to actively participate } \\
\text { Causes a lot of activity among the students }\end{array}$ \\
\hline Competence and self-esteem & 14 & 13 & $\begin{array}{l}\text { This is important because there are students who can feel anxious } \\
\text { and insecure when it comes to different tasks } \\
\text { So that every student can succeed in something } \\
\text { Will promote the students' self-esteem a lot }\end{array}$ \\
\hline Motivation & 24 & 23 & $\begin{array}{l}\text { It promotes their motivation and they feel ... } \\
\text { Good to get students motivated } \\
\text { Will increase the motivation to continue [to practice] }\end{array}$ \\
\hline Enjoyment & 15 & 14 & $\begin{array}{l}\text { It was incredibly fun to do all the tasks } \\
\text { Usually it is also more fun when } \\
\text { I think the students are having fun when they get }\end{array}$ \\
\hline Fluent instruction & 12 & 12 & $\begin{array}{l}\text { So the PE lessons will flow more smoothly and you will ultimately save time } \\
\text { As a teacher, you can assist at that station } \\
\text { Otherwise, there is a great risk that nobody knows what to do }\end{array}$ \\
\hline
\end{tabular}

Note. DMs = didactical milestones; $\mathrm{PE}=$ physical education.

Table 4 A Comparison of Content and Reasons for Practical Knowledge (DMs)

\begin{tabular}{|c|c|c|c|c|c|c|}
\hline Content & Learning & $\begin{array}{c}\text { Active } \\
\text { participation }\end{array}$ & $\begin{array}{l}\text { Competence and } \\
\text { self-esteem }\end{array}$ & Motivation & Enjoyment & $\begin{array}{c}\text { Fluent } \\
\text { instruction }\end{array}$ \\
\hline Activity & 4 & 2 & 2 & 1 & & \\
\hline Individualization & & & 3 & 1 & 1 & \\
\hline Empowerment & 2 & 1 & 1 & 6 & 1 & \\
\hline Planning & 2 & 1 & & & 1 & 5 \\
\hline Modification & & 7 & 1 & 5 & 6 & \\
\hline Teaching methods & 2 & 5 & & 4 & & 2 \\
\hline Progression & & 1 & 4 & 1 & & \\
\hline Concretization & 5 & & & & & \\
\hline Feedback & 2 & & 2 & & 1 & \\
\hline Play & 1 & & & 1 & 3 & \\
\hline Technology & & & & 1 & 1 & 2 \\
\hline Teaching strategies & 3 & 2 & 1 & 4 & 1 & 3 \\
\hline
\end{tabular}

Note. DMs = didactical milestones.

The content of these PCTs' practical knowledge was mainly pedagogical and focused most often on essential principles of teaching and student learning processes, which indeed is the main mission of the teaching profession (Rosenshine, 1979). The majority of the practical knowledge in the present study was related to how to support students' learning processes with appropriate instructional decisions, when general education PCTs' practical knowledge was most often concerned with responsibilities of the teacher, instructional strategies, and classroom environment (Levin \& He, 2008; Pitkäniemi et al., 2014). In addition, data from PETE students (Romar et al., 2018), which are comparable with this study, indicate that the instruction and teacher categories had about one third of each of the total DMs; while in the present study, the instruction category comprised $57 \%$ of the total and the teacher category comprised only 5\%. That TE context appears to heavily influence beliefs and knowledge about instruction is not surprising, given that a major focus in the present study was the practical teaching component developed through experience-based content learning, in which modeling effective PE pedagogy had a unique role (Dack, 2018; Grossman et al., 2000). In addition, the course offered various activities, teaching strategies, resources, and assessments, and featured numerous differentiated learning experiences through which PCTs could construct their practical knowledge along with the coursework (Borko \& Putnam, 1996; Fairbanks et al., 2010). Therefore, the situation-specific nature of teaching and learning underlines the central role of the local context in shaping PCTs' practical knowledge (Ben-Peretz, 2011; Rovegno et al., 2003).

The findings from this study are aligned with those of other practical knowledge scholars (Buitink, 2009; He et al., 2011; Levin \& He, 2008; Maaranen et al., 2016; Pitkäniemi et al., 2014; Romar et al., 2018; Verloop et al., 2001), who suggest that previously 
defined practical knowledge categories (teachers, teaching and instructional activities, classroom context, students, sociocultural aspects, and curriculum) are shared by many preservice and inservice teachers. Although shared components of PCTs' practical knowledge were found among these participants in the same context, each preservice teacher showed a separate pattern, representing a complex range of personal understanding (Elbaz, 1991; Fenstermacher, 1994). In the current study, we split each PCTs' practical knowledge into individual statements and combined them into a full matrix. Therefore, it is impossible to say what a complete practical knowledge, consisting of all the statements from one individual preservice teacher, would look like. Personal differences must and will exist (Elbaz, 1991; Fenstermacher, 1994; Romar et al., 2018), but the purpose of this study was not to analyze practical knowledge as individual products but rather to see what kind of general patterns existed among PCTs.

That fact that we notice shared components of PCTs' practical knowledge and a focus on instruction supports the idea that PCTs' practical knowledge is closely related to TE courses that helped them prepare for teaching PE. Many DMs illustrated that their practical knowledge was in accordance with theoretical conceptions of teaching and learning in PE (Tannehill, Van der Mars, \& MacPhail, 2013). These findings support arguments from Elbaz (1983) and Johnston (1992) that teachers' practical knowledge is practice oriented and used to shape and direct their teaching. Thus, PCTs focused on "how you teach" with increased attention to the instructional process, which would be directly useful for their teaching practice in schools (Herold \& Waring, 2011). Further evidence for the significance of the instructional process is that short-term tips and tricks were evident in the teaching strategies category. This finding is often reported as being generally expected by preservice teachers in PETE (Fletcher \& Casey, 2014). On the other hand, the contents of the PCTs' practical knowledge did not indicate a focus on "what to teach" or content knowledge, and Herold and Waring (2011) noted that many PE preservice teachers considered this a priority during the early stages of their TE program.

One striking issue is the lack of DMs related to teaching context; only a few DMs were identified as such. In other words, context and curriculum had little emphasis in the PCTs' practical knowledge constructed during a PE course, as reported previously in research about preservice teachers (Romar et al., 2018; Stenberg et al., 2014). The lack of context might be explained by the kind of knowledge assessed in the course assignment and the learning content that was taught. It is important to consider the implications of the relative lack of emphasis on context and curriculum by PCTs in this study and realize that more attention must be paid to these issues in TE courses at our university and among other teacher educators.

Missing from previous research is empirical evidence that indicates the reasons for PCTs' practical knowledge, a construction made by themselves in their explicitly stated knowledge. Therefore, the second research question related to the arguments and reasons PCTs had for their practical knowledge identified from their DMs. In other words, we were interested in why they had stated a DM. The PCTs connected specific DMs with their understanding of pedagogical issues, and the present study showed that the students and their learning processes were important to the PCTs' meaning-making processes in relation to teaching PE. Across the five categories related to student learning processes, it is remarkable that PCTs often mention students when discussing reasons for their DMs. This is in accordance with previous findings, as researchers (Stenberg et al., 2014) have noted that preservice teachers have a strong student-oriented approach at the beginning of their TE. Also, Buitink (2009) concluded that student orientation was a criterion for well-developed practical knowledge. This result in the present study may be related to the fact that all PCTs enrolled in the course as an elective, or perhaps based on initial experiences from previous PE classes in school. On the other hand, we do not know what kind of practical knowledge they had at the beginning of the TE program or at the start of this specific PE course. PCTs' understanding is filtered through existing knowledge, beliefs, and disposition during the teacher learning process (Borko \& Putnam, 1996). Therefore, in this course, the teacher educators strived to create a learning environment where student teachers took responsibility for and played an active role in their learning, modeling conceptions of good teaching and learning in PE, and facilitating interactions and learning reflections.

The development of a preservice teacher's ability to consider the teaching process from the learner's perspective might also stem from the fact that these PCTs had several general education studies and methods courses in other subjects. So, although we focus on PE, we cannot discount the other influences that PCTs encounter during their TE program. They learn about teaching in a variety of different contexts, from the lectures to school-based practicum. Different courses also consist of a variety of formal pedagogical structures with diverse academic staff. Although each learning situation is intended to assist in the development of teacher knowledge and skill in specific ways, the PCTs experience is far from coherent or homogenous, and the differing contexts provide competing and challenging concepts that preservice teachers must comprehend (Stenberg et al., 2014). Therefore, a student-centered approach might be evident in many other courses and teaching practices during the TE program, and PCTs use these lenses when they construct practical knowledge in a PE course. Consequently, the PCT gains knowledge in a complex context, not only in an isolated environment, when learning to teach PE (Borg, 2015). Further research in classroom TE and PETE might therefore include the sources for their practical knowledge, as already is reported in general TE literature (Levin \& He, 2008; Stenberg et al., 2014).

In addition, it is necessary to understand the relation between the contents and the reasons for student teachers' practical knowledge if we, as researchers and teacher educators, want to develop such knowledge and teaching practices (Tsangaridou, 2016). In analyzing the link between the content and reason for practical knowledge, several interesting patterns were identified by which DMs were supported with relevant arguments from theoretical perspectives. These findings can be considered logical validations for the link. For example, DMs with a focus on engagement and empowerment were linked to student motivation, and DMs related to task progression were important for student competence and self-esteem. In addition, DMs about how to concretize teaching were linked to student learning. Support for these strong alignments can be found in PE textbooks (see Tannehill et al., 2013).

The findings propose consequences for classroom TE that prepare PCTs with a focus on maintaining support in the learning environment where PE content and pedagogies are reflected and analyzed from a range of perspectives. First, Freak and Miller (2017) noted that the amount of time spent is sometimes as little as $4 \mathrm{hr}$ in many classroom TE programs, and the depth of knowledge offered was generally considered too limited to prepare teachers to teach quality PE. However, in our preservice TE program, all PCTs take a compulsory PE course with a second optional course (five 
credits) presented in this study. Across the semester in this optional course, $64 \mathrm{hr}$ were allocated to face-to-face learning time, and of these, $56 \mathrm{hr}$ were for practical with a focus on experiential learning (Dack, 2018). Accordingly, PCTs typically value practical orientation more highly than the theoretical elements of their studies (Kari, 2016; Puustinen et al., 2018), and here, the practical hours involved teacher educators modeling effective pedagogy and subsequent critical reflection and construction of their practical knowledge. As such, in TE, PCTs should have the time and opportunities to concentrate on issues that will fundamentally affect their future work.

Given the short time that PCTs have to learn to teach PE in TE, it is worth identifying what they actually know, are able to do, and what they value about teaching (Tsangaridou, 2016). However, are there any standards or qualifications as to when PCTs' practical knowledge is acceptable or worthwhile? In addition, can a teacher educator accept whatever practical knowledge their preservice teacher constructs? The present study suggests that specific content areas can be defined and evaluated through the personal construction of knowledge for future work, though it is a challenge. Here, each teacher educator must create an appropriate learning environment with real situations in which PCTs can examine, elaborate, and integrate new experiences and understanding into their existing knowledge and beliefs (Borko \& Putnam, 1996; Fairbanks et al., 2010; Richardson, 2003). Accordingly, real teaching experiences and reflection are important because reflection is developed with practice and influenced by teaching context (Tsangaridou, 2016).

Although the findings in the present study indicated that these PCTs developed practical knowledge for teaching PE, we have no evidence as to whether they lack the skills, confidence, and willingness to teach PE (Dyson et al., 2018; Tsangaridou, 2012), nor did we identify positive and significant changes in their identities as PE teachers or improved self-efficacy for teaching PE (Fletcher et al., 2013). However, based on their interest, performance and practical knowledge during the course, we as teacher educators feel confident about their capabilities to provide quality teaching of elementary school PE.

\section{Conclusion}

As teacher educators, we are interested in finding out whether and how PCTs advance their pedagogical understandings and make gradual development from being a student to becoming a teacher. The content of and reasons for their practical knowledge help us understand what is learned, what they know, and what they value about teaching PE. At the beginning stage of TE, when PCTs must start thinking and acting as teachers, it seemed that these PCTs considered "how to teach" important, and there was a focus on how to apply and adapt teaching content to motivate their learners. Consequently, our study contributes to research on PCT knowledge and its development in PE. Methodologically, the present study has shown the importance of listening to PCTs' voices in assessing teacher knowledge as well as providing quantitative and qualitative descriptions of their practical knowledge. However, this study has certain limitations. Some factors might raise questions about the generalizability of our findings. Due to the explorative nature of this study, the scope was limited to one method of data collection at one Finnish university, and the PCTs were not randomly selected. Our study took place in an ecologically valid context in which the TE curriculum in PE was typical of similar classroom TE programs in Finland and in other European countries. However, limiting the attention to one TE department also allowed deeper insight into
PCTs' practical knowledge in a specific context. In addition, the concept of teacher knowledge has expanded significantly over time and the educational community has used various labels, thus employing another concept may yield different findings. Although this study investigated the learning process during the second year, a logical next step would be to examine the contribution of various learning activities during their subsequent 3 years in our program and/or how these beginning teachers adapt their practical knowledge to day-to-day teaching is schools. Finally, it is hoped that this article informs and stimulates further discussion with regard to the development of effective elementary TE programs for classroom teachers in delivering quality teaching in PE.

\section{References}

Aspfors, J., \& Eklund, G. (2017). Explicit and implicit perspectives on research-based teacher education: Newly qualified teachers' experiences in Finland. Journal of Education for Teaching,, 43, 400-413.

Ben-Peretz, M. (2011). Teacher knowledge: What is it? How do we uncover it? What are its implications for schooling? Teaching and Teacher Education,, 27, 3-9. doi:10.1016/j.tate.2010.07.015

Berliner, D.C. (2004). Expert teachers: Their characteristics, development and accomplishments. Bulletin of Science, Technology and Society,, 24, 200-212. doi:10.1177/0270467604265535

Borg, S. (2003). Teacher cognition in language teaching: A review of research on what language teachers think, know, believe, and do. Language Teaching,, 36, 81-109. doi:10.1017/S0261444803001903

Borg, S. (2015). Teacher cognition and language education: Research and practice. London, UK: Bloomsbury.

Borko, H., \& Putnam, R.T. (1996). Learning to teach. In D.C. Berliner \& R.C. Calfee (Eds.), Handbook of educational psychology (pp. 673708). London, UK: Prentice Hall International.

Buitink, J. (2009). What and how do student teachers learn during schoolbased teacher education. Teaching and Teacher Education, 25, 118 127. doi:10.1016/j.tate.2008.07.009

Carse, N. (2015). Primary teachers as physical education curriculum change agents. European Physical Education Review,, 21, 309-324. doi:10.1177/1356336X14567691

Carse, N., Jess, M., \& Keay, J. (2018). Primary physical education: Shifting perspectives to move forwards. European Physical Education Review, 24, 487-502. doi:10.1177/1356336X16688598

Clandinin, D.J. (1986). Classroom practice: Teacher images in action. London, UK: Falmer.

Dack, H. (2018). Structuring teacher candidate learning about differentiated instruction through coursework. Teaching and Teacher Education, 69, 62-74. doi:10.1016/j.tate.2017.09.017

Dyson, B., Cowan, J., Gordon, B., Powell, D., \& Shulruf, B. (2018). Physical education in Aotearoa New Zealand primary schools: Teachers' perceptions and policy implications. European Physical Education Review, 24, 467-486. doi:10.1177/1356336X17698083

Elbaz, F. (1981). The teacher's "practical knowledge": Report of a case study. Curriculum Inquiry, 11, 43-71.

Elbaz, F. (1983). Teacher thinking. A study of practical knowledge. London, UK: Groom Helm.

Elbaz, F. (1991). Research on teacher's knowledge: The evolution of a discourse. Journal of Curriculum Studies, 23, 1-19. doi:10.1080/ 0022027910230101

Elliot, D.L., Atencio, M., Campbell, T., \& Jess, M. (2013). From PE experiences to PE teaching practices? Insights from Scottish primary teachers' experiences of PE, teacher education, school entry and professional development. Sport, Education and Society, 18, 749766. doi:10.1080/13573322.2011.609165 
Fairbanks, C.M., Duffy, G.G., Faircloth, B.S., He, Y., Levin, B., Rohr, J., \& Stein, C. (2010). Beyond knowledge: Exploring why some teachers are more thoughtfully adaptive than others. Journal of Teacher Education, 61, 161-171. doi:10.1177/0022487109347874.

Fenstermacher, G.D. (1994). The knower and the known: The nature of knowledge in research on teaching. Review of Research in Education, 20, 3-56.

Finnish Advisory Board on Research Integrity. (2016). Responsible conduct in research and procedures for handling allegations of misconduct in Finland. Retrieved from https://www.tenk.fi/en

Fletcher, T., \& Casey, A. (2014). The challenges of models-based practice in physical education teacher education: A collaborative self-study. Journal of Teaching in Physical Education, 33, 403-421. doi:10. 1123/jtpe.2013-0109

Fletcher, T., \& Mandigo, J. (2012). The primary school teacher and physical education: A review of research and implications for Irish physical education. Irish Educational Studies, 31, 363-376. doi:10. 1080/03323315.2012.710063

Fletcher, T., Mandigo, J., \& Kosnik, C. (2013). Elementary classroom teachers and physical education: Change in teacher-related factors during pre-service teacher education. Physical Education and Sport Pedagogy, 18, 169-183. doi:10.1080/17408989.2011.649723

Freak, A., \& Miller, J. (2017). Magnifying pre-service generalist teachers' perceptions of preparedness to teach primary school physical education. Physical Education and Sport Pedagogy, 22, 51-70. doi:10. 1080/17408989.2015.1112775

Grossman, P.L., Valencia, S.W., Evans, K., Thompson, C., Martin, S., \& Place, N. (2000). Transitions into teaching: Learning to teach writing in teacher education and beyond. Journal of Literacy Research, 32, 631-662. doi:10.1080/10862960009548098

Hardman, K. (2005). Rhetoric and reality of school physical education in Europe: The evidence of research. In F. Carreiro Da Costa, M. Cloes, \& M. Gonzalez Valeiro (Eds.), The art and science of teaching in physical education and sport (pp. 63-87). Lisbon, Portugal: Faculdade de Motricidate Humana.

Harfitt, G.J., \& Chan, C. (2017). Constructivist learning theories in teacher education programmes: A pedagogical perspective. In D.J. Clandinin \& J. Husu (Eds.), International handbook of research on teacher education (pp. 545-561). London, UK: Sage.

He, Y., Levin, B.B., \& Li, Y. (2011). Comparing the content and sources of the pedagogical beliefs of Chinese and American pre-service teachers. Journal of Education for Teaching, 37, 155-171. doi:10.1080/ 02607476.2011 .558270

Herold, F.A., \& Waring, M. (2011). So much to learn, so little time ... : Preservice physical education teachers' interpretations and development of subject knowledge as they learn to teach. Evaluation \& Research in Education, 24, 61-77. doi:10.1080/09500790.2010.526203

Hopper, T. (2015). Self-study of an elementary generalist physical education teacher educator: School-integrated teacher education and structural coupling. Asia-Pacific Journal of Health, Sport and Physical Education, 6, 259-272. doi:10.1080/18377122.2015.1092723

Hosein, A., \& Rao, N. (2017). Students' reflective essays as insights into student centred-pedagogies within the undergraduate research methods curriculum. Teaching in Higher Education, 22, 109-125. doi:10. 1080/13562517.2016.1221804

Hyndman, B.P. (2017). Perceived social-ecological barriers of generalist pre-service teachers towards teaching physical education: Findings from the GET-PE study. Australian Journal of Teacher Education, 42(7), 26-46. doi:10.14221/ajte.2017v42n7.3

Johnston, S. (1992). Images: A way of understanding the practical knowledge of student teachers. Teaching and Teacher Education, 8, 123-136. doi:10.1016/0742-051X(92)90003-L
Kari, J. (2016). Hyvä opettaja: luokanopettajaopiskelijat liikuntakokemustensa ja opettajuutensa tulkitsijoina [A good teacher: Class teacher students' interpretations of their exercise history and teacher identity] (Doctoral dissertation). University of Jyväskylä, Jyväskylä, Finland.

Krokfors, L., Kynäslahti, H., Stenberg, K., Toom, A., Maaranen, K., Jyrhämä, R., . . Kansanen, P. (2011). Investigating Finnish teacher educators' views on research-based teacher education. Teaching Education, 22, 1-13. doi:10.1080/10476210.2010.542559

Levin, B., \& He, Y. (2008). Investigating the content and sources of teacher candidates' personal practical theories (PPTs). Journal of Teacher Education, 59, 55-68. doi:10.1177/0022487107310749

Maaranen, K., Pitkäniemi, H., Stenberg, K., \& Karlsson, L. (2016). An idealistic view of teaching: Teacher students' personal practical theories. Journal of Education for Teaching, 42, 80-92. doi:10. 1080/02607476.2015.1135278

Meijer, P.C., Verloop, N., \& Beijaard, D. (2002). Multi-method triangulation in a qualitative study on teachers' practical knowledge: An attempt to increase internal validity. Quality and Quantity, 36, 145167. doi:10.1023/A:1014984232147

Morgan, P., \& Bourke, S. (2008). Non-specialist teachers' confidence to teach PE: The nature and influence of personal school experiences in PE. Physical Education and Sport Pedagogy, 13, 1-29. doi:10.1080/ 17408980701345550

Morgan, P.J., \& Hansen, V. (2008). Classroom teachers' perceptions of the impact of barriers to teaching physical education on the quality of physical education programs. Research Quarterly for Exercise and Sport, 79, 506-516. PubMed ID: 19177952 doi:10.1080/02701367. 2008.10599517

Ni Chróinín, D., \& Coulter, M. (2012). The impact of initial teacher education on understandings of physical education. Asking the right question. European Physical Education Review, 18, 220-238. doi:10. 1177/1356336X12440016

Ni Chróinín, D., \& O’Sullivan, M. (2014). From initial teacher education through induction and beyond: A longitudinal study of primary teacher beliefs. Irish Educational Studies, 33, 451-466. doi:10. 1080/03323315.2014.984387

Oonk, W., Verloop, N., \& Gravemeijer, K.P. (2015). Enriching practical knowledge: Exploring student teachers' competence in integrating theory and practice of mathematics teaching. Journal for Research in Mathematics Education, 46, 559-598. doi:10.5951/jresematheduc. 46.5.0559

Pike, S., \& Fletcher, T. (2014). A review of research on physical education teacher socialization from 2000-2012. PHEnex Journal, 6(1), 1-17.

Pitkäniemi, H. (2017). A teacher's practical theories, self-efficacy, and emotions-what connections do they have, and how can they be developed? Nordisk Tidskrift för Allmän Didaktik, 3, 2-23.

Pitkäniemi, H., Karlsson, L., \& Stenberg, K. (2014). The relationship between Finnish student teachers' practical theories, sources, and teacher education. International Journal of Higher Education, 3, 129-141. doi:10.5430/ijhe.v3n4p129

Puustinen, M., Säntti, J., Koski, A., \& Tammi, T. (2018). Teaching: A practical or research-based profession? Teacher candidates' approaches to research-based teacher education. Teaching and Teacher Education, 74, 170-179. doi:10.1016/j.tate.2018.05.004

Richardson, V. (2003). Constructivist pedagogy. Teachers College Record, 105, 1623-1640. doi:10.1046/j.1467-9620.2003.00303.x

Romar, J.E., Åström, P., \& Ferry, M. (2018). Practical knowledge of preservice physical education teachers: Content and influence of acculturation. Journal of Physical Education and Sport, 18, 114-126.

Rosenshine, B. (1979). Content, time and direct instruction. In P.L. Peterson \& H.J. Walberg (Eds.), Research on teaching (pp. 2856). Berkeley, CA: McCutchan. 
Rovegno, I. (1995). Theoretical perspectives on knowledge and learning and a student teacher's pedagogical content knowledge of dividing and sequencing subject matter. Journal of Teaching in Physical Education, 14, 284-304. doi:10.1123/jtpe.14.3.284

Rovegno, I., Chen, W., \& Todorovich, J. (2003). Accomplished teachers' pedagogical content knowledge of teaching dribbling to third grade children. Journal of Teaching in Physical Education, 22, 426-449. doi:10.1123/jtpe.22.4.426

Siedentop, D., \& Tannehill, D. (2000). Developing teaching skills in physical education (4th ed.). Palo Alto, CA: Mayfield.

Silverman, D. (2011). Interpreting qualitative data: A guide to the principles of qualitative research. London, UK: Sage.

Stenberg, K., Karlsson, L., Pitkäniemi, H., \& Maaranen, K. (2014). Beginning student teachers' teacher identities based on their practical theories. European Journal of Teacher Education, 37, 204-219. doi:10.1080/02619768.2014.882309

Tannehill, D., Van der Mars, H., \& MacPhail, A. (2013). Building effective physical education programs. Burlington, MA: Jones \& Bartlett Publishers.

Templin, T.J., \& Richards, K.A.R. (2014). CH McCloy lecture: Reflections on socialization into physical education: An intergenerational perspective. Research Quarterly for Exercise and Sport, 85, 431-445. PubMed ID: 25412124 doi:10.1080/02701367.2014. 964635

Templin, T.J., \& Schempp, P.G. (1989). Socialization into physical education: Its heritage and hope. In T.J. Templin \& P.G. Schempp (Eds.), Socialization into physical education: Learning to teach (pp. 1-11). Indianapolis, IN: Benchmark.
Tsangaridou, N. (2002). Enacted pedagogical content knowledge in physical education: A case study of a prospective classroom teacher. European Physical Education Review, 8, 21-36. doi:10.1177/ 1356336X020081002

Tsangaridou, N. (2012). Educating primary teachers to teach physical education. European Physical Education Review, 18, 275-286. doi:10.1177/1356336X12450788

Tsangaridou, N. (2016). Moving towards effective physical education teacher education for generalist primary teachers: A view from Cyprus. Education 3-13,, 44, 632-647. doi:10.1080/03004279.2014. 952757

Van Driel, J.H., Beijaard, D., \& Verloop, N. (2001). Professional development and reform in science education: The role of teachers' practical knowledge. Journal of Research in Science Teaching, 38, 137-158. doi:10. 1002/1098-2736(200102)38:2<137::AID-TEA1001>3.0.CO;2-U

Verloop, N., Van Driel, J., \& Meijer, P. (2001). Teacher knowledge and the knowledge base of teaching. International Journal of Educational Research, 35, 441-461. doi:10.1016/S0883-0355(02)00003-4

Webster, C.A. (2011). Relationships between personal biography and changes in preservice classroom teachers' physical activity promotion competence and attitude. Journal of Teaching in Physical Education, 30, 320-339. doi:10.1123/jtpe.30.4.320

Witterholt, M., Goedhart, M., \& Suhre, C. (2016). The impact of peer collaboration on teachers' practical knowledge. European Journal of Teacher Education, 39, 126-143. doi:10.1080/02619768.2015. 1109624

Yin, R.K. (2017). Case study research and applications: Design and methods. Thousand Oaks, CA: Sage. 